\title{
ENZYME COMPLEX SUPPLEMENTATION ON THE PERFORMANCE OF SWINE IN GROWTH AND FINISHING PHASES ${ }^{1}$
}

\author{
NATÁLIA YOKO SITANAKA ${ }^{2 *}$, FÁBIO ENRIQUE LEMOS BUDIÑO² ${ }^{2}$, SIMONE RAYMUNDO DE OLIVEIRA ${ }^{3}$, ANDREIA \\ DONIZETE CHAGAS VILAS BOAS ${ }^{2}$, JOSÉ EVANDRO DE MORAES ${ }^{2}$
}

\begin{abstract}
The objective of this study was to evaluate the use of an enzyme complex- $\alpha$-amylase, $\beta$ glucanase, phytase, cellulase, xylanase and protease - in the feed of swine in growing and finishing phases, by assessing their performance (daily weight gain, daily feed intake, and feed conversion), dry matter, crude protein, and crude energy apparent digestibility, and the feed costs. Eighty pigs-castrated males, and females - of approximately 63 days of age and initial weight of $20.18 \pm 1.98 \mathrm{~kg}$ were distributed in a $5 \times 2$ factorial arrangement (diet $\times$ sex), in a randomized block design, with eight replications. The treatments used were: positive control diet consisted of $3,300 \mathrm{kcal} / \mathrm{kg}$ in the growth-I phase, and $3,250 \mathrm{kcal} / \mathrm{kg}$ in the growth-II and finishing phases; negative control diet with energy reduction of $85 \mathrm{kcal} / \mathrm{kg}$ of metabolizable energy (ME) (NC85); NC85 diet with addition of enzyme complex (EC85); negative control diet with energy reduction of $100 \mathrm{kcal} / \mathrm{kg} \mathrm{ME} \mathrm{(NC100);} \mathrm{NC100} \mathrm{diet} \mathrm{with} \mathrm{addition} \mathrm{of} \mathrm{enzyme} \mathrm{complex} \mathrm{(EC100).} \mathrm{The} \mathrm{addition} \mathrm{of} \mathrm{the} \mathrm{enzyme}$ complex to the diet with energy reduction of $100 \mathrm{kcal} / \mathrm{kg} \mathrm{ME}$ increased the digestible protein content of the diet for the swine in the growth-II phase. The addition of the enzyme complex to the diet with energy reduction of 85 and $100 \mathrm{kcal} / \mathrm{kg} \mathrm{ME}$ increased the digestible energy content of the diets for the swine in the finishing phase. The use of enzyme complex in diets with reduction of $85 \mathrm{kcal} / \mathrm{kg} \mathrm{ME}$ for male swine in growing and finishing phases is recommended for improving feed conversion and economic efficiency during the growth-I phase. The use of enzyme complex is not justified for female swine.
\end{abstract}

Keywords: Additives. Efficiency. Enzymes. Nutrition.

\section{SUPLEMENTAÇÃO DE COMPLEXO ENZIMÁTICO NO DESEMPENHO DE SUÍNOS EM CRESCIMENTO E TERMINAÇÃO}

\begin{abstract}
RESUMO - O estudo teve como objetivo avaliar o uso de um complexo enzimático contendo $\alpha$-amilase, $\beta$ glucanase, fitase, celulase, xilanase e protease na dieta de suínos em crescimento e terminação sobre o desempenho (ganho diário de peso, consumo diário de ração e conversão alimentar), digestibilidade aparente da matéria seca, proteína bruta, energia bruta e custos de alimentação. Foram utilizados 80 suínos (machos castrados e êmeas), com aproximadamente 63 dias de idade, com peso inicial médio de 20,18 $\pm 1,98 \mathrm{~kg}$, distribuídos em arranjo fatorial $5 \times 2$ (dietas x sexo), em delineamento de blocos ao acaso. Foram testados cinco tratamentos com oito repetições, sendo: CP: Dieta controle positivo $(3300 \mathrm{kcal} / \mathrm{kg}$ na fase crescimento I e 3250 $\mathrm{kcal} / \mathrm{kg}$ nas fases crescimento II e terminação)1; CN85: Dieta controle negativo com redução energética (85 kcal/kg EM); CE85: Dieta CN85 com adição de complexo enzimático; CN100: Dieta controle negativo com redução energética (100 kcal/kg EM); CE100: Dieta CN100 com adição de complexo enzimático. Nas dietas com redução energética de $100 \mathrm{kcal} / \mathrm{kg}$ de EM, o uso do complexo enzimático elevou o teor de proteína digestível durante o Crescimento II. A adição de complexo enzimático nas dietas com redução energética de 85 e $100 \mathrm{kcal} / \mathrm{kg}$ de EM aumentou os teores de energia digestível nas dietas de Terminação. Os resultados mostraram que para machos, recomenda-se o uso de complexo enzimático em dietas com redução de $85 \mathrm{kcal} / \mathrm{kg}$ de EM, durante os períodos de crescimento e terminação, pois melhora a conversão alimentar e é economicamente mais eficiente durante o Crescimento I. Para fêmeas, o uso do complexo enzimático não se justifica.
\end{abstract}

Palavras-chave: Aditivos. Eficiência. Enzimas. Nutrição.

\footnotetext{
${ }^{*}$ Corresponding author

${ }^{1}$ Received for publication in $04 / 21 / 2017$; accepted in 10/23/2017.

Paper extracted from the masters dissertation of the first author.

${ }^{2}$ Instituto de Zootecnia, Nova Odessa, SP, Brazil; natysitanaka@gmail.com - ORCID: 0000-0001-7519-643X, fbudino@iz.sp.gov.br ORCID: 0000-0002-4129-6763, andreiachgs@hotmail.com - ORCID: 0000-0002-8557-3195, evandromoraes0906@gmail.com - ORCID: 0000-0002-9105-6661.

${ }^{3}$ Research and Development Unit of Tanquinho, Agência Paulista de Tecnologia dos Agronegócios, Piracicaba, SP, Brazil; simone@apta.sp.gov.br - ORCID: 0000-0001-8306-9780.
}

Rev. Caatinga, Mossoró, v. 31, n. 3, p. 748 - 758, jul. - set., 2018 


\section{INTRODUCTION}

Feeding is the main cost in swine production, thus, researches have been developed to find ingredients and additives that improve the animal performance and reduce costs. In addition, excess nutrients in feed is a greater concern because of environmental pollution. Therefore, diets must meet the animal's nutritional requirements and promote high digestibility to lower nutrients concentration in excreta.

Enzymes are responsible for food digestion; however, swine are not able to produce enzymes that digest fibrous compounds. The use of exogenous enzymes that degrade fibers assists in the rupture of the cell wall, allowing enzymes produced by the animal to access the interior of the cells of grains, and releasing absorbable nutrients, improving the metabolization of energy and productive performance of animals (LIMA et al., 2007).

The use of exogenous enzymes in swine and poultry feed has been studied to improve feeds by favoring hydrolysis of compounds of low digestibility, such as non-starch polysaccharides (KIARIE; ROMERO; NYACHOTI, 2013).

Most diets formulated for monogastrics in Brazil are based on corn, and soybean meal, which are ingredients of high digestibility. However, feeds containing cereals of lower digestibility, such as triticale, oats, and barley has been used for swine in some studies using enzymes (MATHLOUTHI et al., 2002; HAUSCHILD et al., 2008; LORENAREZENDE et al., 2012).

Soybean meal and corn have high nutritional variability. The composition of corn can vary within and between regions (CANTARELLI et al., 2007; CARVALHO et al., 2009). Soybean meal has variable composition, and its quality is highly dependent on its processing (LUDKE et al., 2007; CARVALHO et al., 2008). Consequently, antinutritional variation of its constituents can occur, compromising the activity of enzymes in the animal.

The addition of an enzyme complex in corn-soybean-based diets aims to better use the nutrients of the diet to improve productivity. The expected benefit is the synergistic effect of enzyme activities in specific components that improves the animal performance (CARDOSO et al., 2010).

The objective of this study was to evaluate the use of an enzyme complex in the feed of swine in growing and finishing phases, by assessing their performance, dry matter, crude protein, and crude energy apparent digestibility, and the economic feasibility of the use of this additive.

\section{MATERIAL AND METHODS}

The experiment was conducted in the Swine Experimental Unit, in the Center-South Unit of the Agribusiness Technology Agency of São Paulo (APTA/SAA, SP), Tanquinho SP, Brazil, from September 16 to December 10, 2014.

Eighty pigs -42 castrated males, and 38 females - of approximately 63 days of age and initial weight of $20.18 \pm 1.98 \mathrm{~kg}$ were used. Each animal was hosted in a pen of $1.00 \times 2.00 \mathrm{~m}$ with flat concrete floor, metal partitions, and semi-automatic feeders and waterers. The experimental barn was made of concrete and was 3.40 meters high; it had side windows for ventilation and temperature control.

The animals were distributed in a randomized block design with a $2 \times 5$ factorial arrangement (diets $\times$ sex). The initial weight of the animals and their sex was considered in the formation of the blocks.

Five experimental diets with and without addition of enzyme complex were evaluated with eight repetitions. The diets used were: positive control diet consisted of $3,300 \mathrm{kcal} / \mathrm{kg}$ in the growth-I phase (GI), and $3,250 \mathrm{kcal} / \mathrm{kg}$ in the growth-II (GII) and finishing (F) phases; negative control diet with energy reduction of $85 \mathrm{kcal} / \mathrm{kg}$ of metabolizable energy (ME) (NC85); NC85 diet with addition of enzyme complex (EC85); negative control diet with energy reduction of $100 \mathrm{kcal} / \mathrm{kg} \mathrm{ME}$ (NC100); NC100 diet with addition of enzyme complex (EC100).

The enzyme complex used consisted of $\alpha$-amylase (400 $\left.\mathrm{U} \mathrm{g}^{-1}\right)$, ß-glucanase (700 $\mathrm{U} \mathrm{g}^{-1}$ ), phytase $\left(1,100 \mathrm{U} \mathrm{g}^{-1}\right)$, cellulase $\left(6,000 \quad \mathrm{U} \mathrm{g}^{-1}\right)$, xylanase $\left(10,000 \mathrm{U} \mathrm{g} \mathrm{g}^{-1}\right)$, and protease $\left(700 \mathrm{U} \mathrm{g}^{-1}\right)$. The nutritional matrix of the enzyme complex was used in the formulation of the diets (Table 1).

The feed program used had 3 phases: growth-I (GI) for animals of 63 to 90 days of age; growth-II (GII) for animals of 91 to 118 days of age; and finishing (F) for animals of 119 to 145 days of age.

The feeds were composed with corn, and soybean meal, according to the minimum nutritional recommendations proposed by Rostagno et al. (2011) for each phase (Tables 2, 3 and 4), and supplied ad libitum. 
Table 1. Nutritional matrix of the enzyme complex used in the diets.

\begin{tabular}{lcc}
\hline & \multicolumn{2}{c}{ Nutritional matrix $\left(\mathrm{g} \mathrm{Mg}^{-1}\right)$} \\
\hline Phosphorus & Diet of $350 \mathrm{~g} \mathrm{Mg}^{-1}$ & Diet of $500 \mathrm{~g} \mathrm{Mg}^{-1}$ \\
Calcium & 315 & 240 \\
Lysine & 329 & 250 \\
Methionine & 34 & 30 \\
Methionine + cysteine & 11 & 10 \\
Threonine & 23 & 32 \\
Tryptophan & 37 & 20 \\
Arginine & 9 & 8 \\
Valine & 26 & 24 \\
Isoleucine & 29 & 26 \\
Crude protein & 34 & 30 \\
Metabolizable Energy (Kcal/kg) & 1714 & 1500 \\
& 242,854 & 200,000 \\
\hline
\end{tabular}

Table 2. Composition $\left(\mathrm{kg} \mathrm{Mg}^{-1}\right)$ of the experimental diets supplied to swine in the growth-I phase (63 to 90 days old).

\begin{tabular}{lrrrrr}
\hline & PC & NC85 & EC85 & NC100 & EC100 \\
\hline Corn (grain) 7.5\% & 669.88 & 703.89 & 703.89 & 709.79 & 709.79 \\
Soybean meal 46\% & 253.00 & 246.00 & 246.00 & 244.00 & 244.00 \\
Soybean oil & 32.00 & 10.50 & 10.50 & 7.00 & 7.00 \\
Limestone 37\% & 7.00 & 8.20 & 8.20 & 8.30 & 8.30 \\
Common salt & 5.00 & 5.00 & 5.00 & 5.00 & 5.00 \\
Dicalcium phosphate 18\% & 17.00 & 10.50 & 10.50 & 10.00 & 10.00 \\
Kaolin & 10.50 & 10.50 & 10.15 & 10.50 & 10.00 \\
Dl-methionine 99\% & 0.42 & 0.32 & 0.32 & 0.31 & 0.31 \\
L-lysine 78\% & 2.20 & 2.20 & 2.20 & 2.20 & 2.20 \\
L-threonine 98\% & 0.50 & 0.39 & 0.39 & 0.40 & 0.40 \\
Choline chloride 60\% & 0.50 & 0.50 & 0.50 & 0.50 & 0.50 \\
Enzyme complex & 0.00 & 0.00 & 0.35 & 0.00 & 0.50 \\
Vitamin supplement ${ }^{1}$ & 1.00 & 1.00 & 1.00 & 1.00 & 1.00 \\
Mineral supplement ${ }^{2}$ & 1.00 & 1.00 & 1.00 & 1.00 & 1.00 \\
\hline Calculated composition & & & & & 17.32 \\
\hline Crude Protein (\%) & 16.69 & 16.61 & 17.21 & 16.57 & 3.49 \\
Ethereal Extract (\%) & 5.85 & 3.82 & 3.82 & 3.49 & 2.83 \\
Gross Fiber (\%) & 2.80 & 2.83 & 2.83 & 2.83 & 5.34 \\
Mineral Matter (\%) & 5.93 & 5.40 & 5.40 & 5.34 & 0.77 \\
Calcium (\%) & 0.77 & 0.65 & 0.77 & 0.64 & 0.49 \\
Total Phosphorus (\%) & 0.61 & 0.50 & 0.50 & 0.49 & 0.40 \\
Available Phosphorus (\%) & 0.40 & 0.29 & 0.40 & 0.28 & 0.21 \\
Sodium (\%) & 0.21 & 0.21 & 0.21 & 0.21 & 3,300 \\
Metabolizable Energy (kcal/kg) & & 3,215 & 3,300 & 3,200 & 0.93 \\
Digestible lysine (\%) & 0.93 & 0.92 & 0.93 & 0.91 & 0.27 \\
Digestible methionine (\%) & 0.27 & 0.26 & 0.27 & 0.26 & 0.52 \\
Digestible methionine + cysteine (\%) & 0.52 & 0.51 & 0.52 & 0.51 & 0.16 \\
Tryptophan digestible (\%) & 0.16 & 0.16 & 0.17 & 0.16 & 0.58 \\
Digestible threonine (\%) & 0.58 & 0.56 & 0.58 & 0.56 & 0.62 \\
Digestible isoleucine (\%) & 0.61 & 0.61 & 0.62 & 0.60 & 0.67 \\
Digestible valine (\%) & 0.67 & 0.66 & 0.67 & 0.65 & \\
\hline & & & & & \\
& 3,300 & & & \\
\end{tabular}

$\mathrm{PC}=$ Positive control diet; NC85 = Negative control diet with energy reduction of $85 \mathrm{kcal} / \mathrm{kg}$ ME; EC $85=\mathrm{NC} 85$ diet with addition of enzyme complex; $\mathrm{NC100}=$ Negative control diet with energy reduction of $100 \mathrm{kcal} / \mathrm{kg} \mathrm{ME}$; $\mathrm{EC} 100=\mathrm{NC100}$ diet with addition of enzyme complex. ${ }^{1}=$ Minimum levels per $\mathrm{kg}$ of feed $=$ Vitamin A (5000 UI), Vitamin D3 (5000 UI), Vitamin E (40 mg), Vitamin K3 (40 mg), Vitamin B1 (1.1 mg), Vitamin B2 (0.2 mg), Vitamin B6 (0.8 mg), Vitamin B12 $(0.1 \mathrm{mg})$, Niacin $(8.5 \mathrm{mg})$, Folic acid $(0.014 \mathrm{mg})$, Biotin $(0.02 \mathrm{mg})$, Selenium $(0.125 \mathrm{mg}) .{ }^{2}=$ Minimum levels per $\mathrm{kg}$ of feed $=$ Iron $(0.234 \mathrm{mg})$, Copper $(0.286 \mathrm{mg})$, Zinc $(0.127 \mathrm{mg})$, Manganese $(0.106 \mathrm{mg})$, Iodine $(0.0017 \mathrm{mg})$. 
Table 3. Composition $\left(\mathrm{kg} \mathrm{Mg}^{-1}\right)$ of the experimental diets supplied to swine in the growth-II phase (91 to 118 days old).

\begin{tabular}{|c|c|c|c|c|c|}
\hline & $\mathrm{PC}$ & NC85 & EC85 & $\mathrm{NC} 100$ & $\mathrm{EC} 100$ \\
\hline Corn (grain) $7.5 \%$ & 720.10 & 740.89 & 740.89 & 737.36 & 737.36 \\
\hline Soybean meal 46\% & 225.00 & 219.00 & 219.00 & 218.00 & 218.00 \\
\hline Soybean oil & 16.50 & 0.00 & 0.00 & 0.00 & 0.00 \\
\hline Limestone $37 \%$ & 7.50 & 8.30 & 8.30 & 8.50 & 8.50 \\
\hline Common salt & 5.00 & 5.00 & 5.00 & 5.00 & 5.00 \\
\hline Dicalcium phosphate $18 \%$ & 10.00 & 4.00 & 4.00 & 3.40 & 3.40 \\
\hline Kaolin & 10.50 & 17.55 & 17.20 & 22.50 & 22.00 \\
\hline Dl-methionine $99 \%$ & 0.40 & 0.34 & 0.34 & 0.33 & 0.33 \\
\hline L-lysine $78 \%$ & 2.00 & 2.00 & 2.00 & 2.00 & 2.00 \\
\hline L-threonine $98 \%$ & 0.50 & 0.42 & 0.42 & 0.41 & 0.41 \\
\hline Choline chloride $60 \%$ & 0.50 & 0.50 & 0.50 & 0.50 & 0.50 \\
\hline Enzyme complex & 0.00 & 0.00 & 0.35 & 0.00 & 0.50 \\
\hline Vitamin supplement $^{1}$ & 1.00 & 1.00 & 1.00 & 1.00 & 1.00 \\
\hline Mineral supplement $^{2}$ & 1.00 & 1.00 & 1.00 & 1.00 & 1.00 \\
\hline \multicolumn{6}{|l|}{ Calculated composition } \\
\hline Crude Protein (\%) & 15.77 & 15.65 & 16.25 & 15.58 & 16.33 \\
\hline Ethereal Extract (\%) & 4.44 & 2.86 & 2.86 & 2.85 & 2.85 \\
\hline Gross Fiber (\%) & 2.74 & 2.74 & 2.74 & 2.73 & 2.73 \\
\hline Mineral Matter (\%) & 5.20 & 5.34 & 5.34 & 5.76 & 5.76 \\
\hline Calcium (\%) & 0.61 & 0.49 & 0.61 & 0.48 & 0.61 \\
\hline Total Phosphorus (\%) & 0.48 & 0.38 & 0.38 & 0.36 & 0.36 \\
\hline Available Phosphorus (\%) & 0.28 & 0.17 & 0.28 & 0.16 & 0.28 \\
\hline Sodium $(\%)$ & 0.21 & 0.21 & 0.21 & 0.21 & 0.21 \\
\hline Metabolizable Energy (kcal/kg) & 3,250 & 3,165 & 3,250 & 3,150 & 3,250 \\
\hline Digestible lysine (\%) & 0.94 & 0.92 & 0.94 & 0.92 & 0.94 \\
\hline Digestible methionine (\%) & 0.85 & 0.84 & 0.85 & 0.84 & 0.85 \\
\hline Digestible methionine + cysteine $(\%)$ & 0.26 & 0.25 & 0.25 & 0.25 & 0.25 \\
\hline Tryptophan digestible (\%) & 0.50 & 0.49 & 0.50 & 0.49 & 0.50 \\
\hline Digestible threonine (\%) & 0.15 & 0.15 & 0.15 & 0.15 & 0.15 \\
\hline Digestible isoleucine (\%) & 0.55 & 0.54 & 0.55 & 0.53 & 0.55 \\
\hline Digestible valine (\%) & 0.57 & 0.56 & 0.58 & 0.56 & 0.58 \\
\hline Crude Protein $(\%)$ & 0.62 & 0.62 & 0.63 & 0.62 & 0.63 \\
\hline
\end{tabular}

$\mathrm{PC}=$ Positive control diet; NC85 = Negative control diet with energy reduction of $85 \mathrm{kcal} / \mathrm{kg}$ ME; EC $85=\mathrm{NC} 85$ diet with addition of enzyme complex; NC100 = Negative control diet with energy reduction of $100 \mathrm{kcal} / \mathrm{kg} \mathrm{ME}$; EC100 $=$ NC100 diet with addition of enzyme complex. ${ }^{1}=$ Minimum levels per $\mathrm{kg}$ of feed $=$ Vitamin A (5000 UI), Vitamin D3 (5000 UI), Vitamin E (40 mg), Vitamin K3 (40 mg), Vitamin B1 (1.1 mg), Vitamin B2 $(0.2 \mathrm{mg})$, Vitamin B6 $(0.8 \mathrm{mg})$, Vitamin B12 $(0.1 \mathrm{mg})$, Niacin $(8.5 \mathrm{mg})$, Folic acid $(0.014 \mathrm{mg})$, Biotin $(0.02 \mathrm{mg})$, Selenium $(0.125 \mathrm{mg}) .{ }^{2}=$ Minimum levels per $\mathrm{kg}$ of feed $=$ Iron $(0.234 \mathrm{mg})$, Copper $(0.286 \mathrm{mg})$, Zinc $(0.127 \mathrm{mg})$, Manganese $(0.106 \mathrm{mg})$, Iodine $(0.0017 \mathrm{mg})$.

The animals, feeds, and leftovers in the feeders were weighed every 15 days to determine the daily weight gain (DWG) in kg per day, daily feed intake (DFI) kg per day, and feed conversion (FC). The feed wasted in the feeding process was collected, weighed, and subtracted from the amount supplied.

The results of performance and feeding costs were analyzed cumulatively: Period I (63-90 days old), Period II (63-118 days old) and Period III (63-145 days old).

Stool samples were collected only from male animals-8 animals per treatment-in the intermediate period of each phase (GI, GII and F), totaling 120 stool samples and 15 feed samples. The experimental diets were supplemented with $1 \%$ Celite ${ }^{\circledR}$, and the animals were fed this feed for three days to regulate the flow of the indicator in the 
digestive tract. Three days after this adaptation, stool samples were collected immediately after defecation, twice a day, in the morning and in the afternoon. The samples were stored in a freezer at $-8^{\circ} \mathrm{C}$ until laboratory analysis, when they were subjected to pre-drying in a forced-air circulation oven at $55^{\circ} \mathrm{C}$ for 72 hours, and milled in a knife mill equipped with 1-mm mesh sieves. Feed samples were only ground, following the same procedures described for the stool.

Table 4. Composition $\left(\mathrm{kg} \mathrm{Mg}^{-1}\right)$ of the experimental diets supplied to swine in the finishing phase (119 to 145 days old).

\begin{tabular}{|c|c|c|c|c|c|}
\hline & $\mathrm{PC}$ & NC85 & EC85 & NC100 & $\mathrm{EC} 100$ \\
\hline Corn (grain) $7.5 \%$ & 761.83 & 773.81 & 773.81 & 770.06 & 770.06 \\
\hline Soybean meal $46 \%$ & 191.00 & 184.00 & 184.00 & 183.00 & 183.00 \\
\hline Soybean oil & 12.60 & 0.00 & 0.00 & 0.00 & 0.00 \\
\hline Limestone $37 \%$ & 6.00 & 6.90 & 6.90 & 7.00 & 7.00 \\
\hline Common salt & 5.00 & 5.00 & 5.00 & 5.00 & 5.00 \\
\hline Dicalcium phosphate $18 \%$ & 8.50 & 2.40 & 2.40 & 1.90 & 1.90 \\
\hline Kaolin & 10.50 & 23.35 & 23.00 & 28.50 & 28.00 \\
\hline Dl-methionine $99 \%$ & 0.21 & 0.18 & 0.18 & 0.18 & 0.18 \\
\hline L-lysine $78 \%$ & 1.85 & 1.90 & 1.90 & 1.90 & 1.90 \\
\hline L-threonine $98 \%$ & 0.51 & 0.46 & 0.46 & 0.46 & 0.46 \\
\hline Choline chloride $60 \%$ & 0.30 & 0.30 & 0.30 & 0.30 & 0.30 \\
\hline Enzyme complex & 0.00 & 0.00 & 0.35 & 0.00 & 0.50 \\
\hline Vitamin supplement $^{1}$ & 0.70 & 0.70 & 0.70 & 0.70 & 0.70 \\
\hline Mineral supplement $^{2}$ & 1.00 & 1.00 & 1.00 & 1.00 & 1.00 \\
\hline \multicolumn{6}{|l|}{ Calculated composition } \\
\hline Crude Protein (\%) & 14.51 & 14.28 & 14.88 & 14.20 & 14.95 \\
\hline Ethereal Extract (\%) & 4.15 & 2.93 & 2.93 & 2.91 & 2.91 \\
\hline Gross Fiber (\%) & 2.62 & 2.60 & 2.60 & 2.59 & 2.59 \\
\hline Mineral Matter (\%) & 4.72 & 5.41 & 5.41 & 5.85 & 5.85 \\
\hline Calcium (\%) & 0.51 & 0.39 & 0.51 & 0.39 & 0.51 \\
\hline Total Phosphorus (\%) & 0.45 & 0.34 & 0.34 & 0.33 & 0.33 \\
\hline Available Phosphorus (\%) & 0.25 & 0.14 & 0.25 & 0.13 & 0.25 \\
\hline Sodium (\%) & 0.21 & 0.21 & 0.21 & 0.21 & 0.21 \\
\hline Metabolizable Energy (kcal/kg) & 3,250 & 3,165 & 3,250 & 3,150 & 3,250 \\
\hline Digestible lysine (\%) & 0.76 & 0.75 & 0.76 & 0.74 & 0.76 \\
\hline Digestible methionine (\%) & 0.22 & 0.22 & 0.22 & 0.22 & 0.22 \\
\hline Digestible methionine + cysteine $(\%)$ & 0.45 & 0.45 & 0.45 & 0.44 & 0.45 \\
\hline Tryptophan digestible (\%) & 0.13 & 0.13 & 0.13 & 0.13 & 0.13 \\
\hline Digestible threonine (\%) & 0.51 & 0.50 & 0.51 & 0.49 & 0.51 \\
\hline Digestible isoleucine (\%) & 0.52 & 0.50 & 0.52 & 0.50 & 0.52 \\
\hline Digestible valine (\%) & 0.57 & 0.57 & 0.57 & 0.56 & 0.57 \\
\hline
\end{tabular}

$\mathrm{PC}=$ Positive control diet; NC85 = Negative control diet with energy reduction of $85 \mathrm{kcal} / \mathrm{kg}$ ME; EC $85=\mathrm{NC} 85$ diet with addition of enzyme complex; $\mathrm{NC100}=$ Negative control diet with energy reduction of $100 \mathrm{kcal} / \mathrm{kg} \mathrm{ME}$; $\mathrm{EC} 100=\mathrm{NC100}$ diet with addition of enzyme complex. ${ }^{1}=$ Minimum levels per $\mathrm{kg}$ of feed $=$ Vitamin A (5000 UI), Vitamin D3 (5000 UI), Vitamin E (40 mg), Vitamin K3 (40 mg), Vitamin B1 (1.1 mg), Vitamin B2 (0.2 mg), Vitamin B6 $(0.8 \mathrm{mg})$, Vitamin B12 $(0.1 \mathrm{mg})$, Niacin $(8.5 \mathrm{mg})$, Folic acid (0.014 mg), Biotin $(0.02 \mathrm{mg})$, Selenium $(0.125 \mathrm{mg}){ }^{2}=$ Minimum levels per $\mathrm{kg}$ of feed $=$ Iron $(0.234 \mathrm{mg})$, Copper $(0.286 \mathrm{mg})$, Zinc $(0.127 \mathrm{mg})$, Manganese $(0.106 \mathrm{mg})$, Iodine $(0.0017 \mathrm{mg})$. 
Processed stool and feed samples were analyzed in the Bromatology Laboratory of the Zootechnics Institute, in a calorimetric bomb (IKA, C5001), to determine their dry matter (DM), crude protein $(\mathrm{CP})$ and crude energy $(\mathrm{CE})$ contents.

The ash in the feed and stools were determined in insoluble acid according to the method adapted by Van Keulen and Young (1977). The indigestibility factor and the coefficients of determination of digestibility of each nutrient were calculated by the methodology described by Sakomura and Rostagno (2016). The data were analyzed in the program SISVAR (FERREIRA, 2011), using the Tukey's test at 5\% significance.

The economic feasibility analysis was conducted for each phase and for the total period of the experiment. The feed cost (BRL) per $\mathrm{kg}$ of live-weight gain was determined (BELLAVER et al., 1985). Then, the Economic Efficiency Index (EEI) was calculated, as suggested by Tavernari et al. (2009). The prices of the ingredients used to calculate the costs of the diets were based on the prices found in the State of São Paulo, Brazil, in August 13, 2013, considering USS $1.00=$ BRL 2.60.

\section{RESULTS AND DISCUSSION}

The results of the daily feed intake (DFI), daily weight gain (DWG), and feed conversion (FC) of the female swine, in the three evaluated periods are shown in Table 5.

The performance of the females in the Periods I and III was similar $(p>0.05)$, regardless of the diets. Kim et al. (2006) found similar result, with no significant effects of diets with enzymes on the performance of swine in growing phase.

Table 5. Performance of female swine fed diets with or without enzyme complex in growth and finishing phases.

\begin{tabular}{cllllllr}
\hline & PC & NC85 & EC85 & NC100 & EC100 & P-value & CV (\%) \\
\hline DWG (kg) & & & & & & & \\
Period I & 0.725 & 0.700 & 0.791 & 0.787 & 0.782 & 0.577 & 17.96 \\
Period II & 0.873 & 0.800 & 0.889 & 0.821 & 0.860 & 0.636 & 15.14 \\
Period III & 0.944 & 0.906 & 0.981 & 0.919 & 0.926 & 0.530 & 9.70 \\
\hline DFI (kg) & & & & & & & \\
Period I & 1.459 & 1.479 & 1.610 & 1.602 & 1.549 & 0.518 & 13.81 \\
Period II & 1.715 & 1.866 & 2.037 & 1.930 & 1.929 & 0.073 & 11.29 \\
Period III & 2.137 & 2.225 & 2.387 & 2.248 & 2.187 & 0.219 & 9.53 \\
\hline FC & & & & & & & \\
Period I & 2.03 & 2.12 & 2.05 & 2.03 & 1.98 & 0.493 & 7.63 \\
Period II & $1.98^{\mathrm{b}}$ & $2.33^{\mathrm{ab}}$ & $2.29^{\mathrm{ab}}$ & $2.38^{\mathrm{a}}$ & $2.24^{\mathrm{ab}}$ & 0.021 & 10.66 \\
Period III & 2.26 & 2.45 & 2.43 & 2.45 & 2.36 & 0.194 & 7.17 \\
\hline
\end{tabular}

Means followed by different letters in the row differ by the Tukey's test $(p<0.05) . \mathrm{PC}=$ Positive control diet; NC85 = Negative control diet with energy reduction of $85 \mathrm{kcal} / \mathrm{kg} \mathrm{ME}$; EC85 = NC85 diet with addition of enzyme complex; NC100 = Negative control diet, with energy reduction of $100 \mathrm{kcal} / \mathrm{kg} \mathrm{ME} ; \mathrm{EC} 100=\mathrm{NC} 100$ diet, with addition of enzyme complex. Period I (63-90 days old); Period II (63-118 days old); Period III (63-145 days old). $\mathrm{DWG}=$ daily weight gain; $\mathrm{DFI}=$ daily feed intake; $\mathrm{FC}=$ feed conversion; $\mathrm{CV}=$ coefficient of variation .

In Period II, the swine females in the NC85, EC85 NC100 and EC100 diets had the lowest FC $(p<0.05)$. Ruiz et al. (2008) found swine females fed diets containing enzyme complex presenting the lowest FC due to an increased feed consumption, but with no difference in daily weight gain. This increase in feed consumption is due to the energy reduction in the diets, which is the main intake regulation mechanism (LEWIS, 2001).

According to Silva et al. (2013), the lack of positive results in performance with the use of exogenous enzymes in feeds for swine in growing and finishing phases can be caused by insufficient digestibility of nutrients in the diets evaluated or by the sufficient nutritional levels of the diet, which met the animal's nutritionals requirements in the categories evaluated, regardless of the addition of enzymes.

The male swine in Period I had similar DFI and DWG $(p>0.05)$. Although the animals had FC with statistical differences $(p<0.05)$, the positive benefit of using the enzyme complex in the diets was unclear (Table 6).

Animals in the Period II had different FC $(p<0.05)$, despite their similarity in DFI and DWG $(p>0.05)$. Animals that had energy reduction of 85 and $100 \mathrm{kcal}$ showed lower FC, but those that had reduction of $100 \mathrm{kcal}$ and were supplemented with the enzyme complex had similar FC to those under control diet $(p=0.006)$. 
Table 6. Performance of castrated male swine in the growth and finishing phases that were fed diets with or without enzyme complex.

\begin{tabular}{cccccccr}
\hline & PC & NC85 & EC85 & NC100 & EC100 & P-value & CV (\%) \\
\hline DWG (kg) & & & & & & & \\
Period I & 0.802 & 0.610 & 0.752 & 0.753 & 0.794 & 0.187 & 23.08 \\
Period II & 0.943 & 0.764 & 0.896 & 0.852 & 0.935 & 0.050 & 13.87 \\
Period III & $1.054^{\mathrm{a}}$ & $0.811^{\mathrm{b}}$ & $1.013^{\mathrm{a}}$ & $0.955^{\mathrm{ab}}$ & $1.024^{\mathrm{a}}$ & 0.002 & 17.99 \\
\hline DFI (kg) & & & & & & & \\
Period I & 1.264 & 1.186 & 1.241 & 1.300 & 1.341 & 0.458 & 14.44 \\
Period II & 1.722 & 1.758 & 1.923 & 1.874 & 1.967 & 0.215 & 13.08 \\
Period III & 2.257 & 2.079 & 2.361 & 2.311 & 2.434 & 0.102 & 9.58 \\
\hline FC & & & & & & & $1.69^{\mathrm{ab}}$ \\
Period I & $1.63^{\mathrm{b}}$ & $2.12^{\mathrm{a}}$ & $1.66^{\mathrm{ab}}$ & $1.75^{\mathrm{ab}}$ & 0.030 & 1.89 \\
Period II & $1.83^{\mathrm{b}}$ & $2.35^{\mathrm{a}}$ & $2.15^{\mathrm{a}}$ & $2.20^{\mathrm{a}}$ & $2.09^{\mathrm{ab}}$ & 0.006 & 11.26 \\
Period III & $2.14^{\mathrm{c}}$ & $2.59^{\mathrm{a}}$ & $2.33^{\mathrm{bc}}$ & $2.41^{\mathrm{ab}}$ & $2.38^{\mathrm{abc}}$ & 0.003 & 7.09 \\
\hline
\end{tabular}

Means followed by different letters in the row differ by the Tukey's test $(p<0.05)$. PC $=$ Positive control diet; NC85 = Negative control diet with energy reduction of $85 \mathrm{kcal} / \mathrm{kg} \mathrm{ME}$; EC85 = NC85 diet with addition of enzyme complex; NC100 = Negative control diet, with energy reduction of $100 \mathrm{kcal} / \mathrm{kg} \mathrm{ME} ; \mathrm{EC} 100=\mathrm{NC100}$ diet, with addition of enzyme complex. Period I (63-90 days old); Period II (63-118 days old); Period III (63-145 days old). $\mathrm{DWG}=$ daily weight gain; $\mathrm{DFI}=$ daily feed intake; $\mathrm{FC}=$ feed conversion; $\mathrm{CV}=$ coefficient of variation.

In Period III, the different diets of the animals resulted in different DWG $(p<0.05)$, and the FC of those that had diets with energy reduction was lower. The use of enzymes improved the FC in males during the periods studied. The supplementation of exogenous enzymes affected $(p<0.05)$ the DWG and $\mathrm{FC}$ in male animals in the evaluated phases (Table 6). Similar results were found by Rodrigues et al. (2002).

The results showed differences between males and females, with males presenting greater DWG, probably due to their higher feed intake and growth speed (NRC, 2012); however, this was not observed in all evaluated phases.

When analyzing the total period of the experiment (Period III), the FC in males was higher than that in females in the treatment EC85. According to Rodrigues et al. (2002), the sex of the animals may affect the animals' response to enzyme supplementation, which shows the need to prepare specific feeds for males and females during the growth and finishing phases.

Silva et al. (2013) evaluated the performance of castrated male, and female swine, considering the total experimental period (GI, GII, and F phases), and found no differences $(p>0.05)$ in DFI between treatments. However, animals supplemented with an enzyme complex-pectinase $4000 \mu \mathrm{g}^{-1}$, protease $700 \mu \mathrm{g}^{-1}$, phytase $300 \mu \mathrm{g}^{-1}$, B-glucanase $200 \mu \mathrm{g}^{-1}$, xylanase $100 \mu \mathrm{g}^{-1}$, cellulase $40 \mu \mathrm{g}^{-1}$, and amylase $30 \mu \mathrm{g}^{-1}$-added without altering the nutritional levels, presented higher DWG $(p<0.05)$ than those subjected to treatments without the enzyme complex and with lower nutritional levels (SILVA et al., 2013).
A degradation of fibrous carbohydrates in the feed offered to the animals, which can be used as an energy source, is expected with addition of an enzyme complex. Thus, the performance of pigs fed the EC85 and EC100 diets should be similar to those that received diets without energy reduction and enzymes. This was not very evident, but was partially confirmed; the FC and DFI during Period II, and FC in Period III were lower in treatments with enzymes when compared to the PC treatment.

According to Ruiz et al. (2017), carbohydrases, especially endoenzymes, release part of the molecules of fibrous carbohydrates that may be enzymatically used by the pig or its intestinal microbial population. Therefore, the carbohydrate portions released by the exogenous enzymes may be a source of energy for the animal or simply be excreted.

The results of the digestibility analysis in the three experimental periods are shown in Table 7.

Despite the differences $(p<0.05)$ between the treatments during growth-I, the digestibility analysis showed that the addition of the enzyme complex improved the coefficients of digestibility of dry matter (CDDM), crude protein (CDCP), crude energy (CDCE), and the values of digestible dry matter (ADDM) and digestible protein (DP).

The reduction of $85 \mathrm{kcal}$ in the feed energy content result in the lowest $(p<0.05)$ digestible energy (DE), when compared to the PC diet, regardless of the addition of the enzyme complex. The reduction of $100 \mathrm{kcal}$ resulted in similar DE $(p>0.05)$ to those found in the PC diet, regardless of the addition of the enzyme complex. 
N. Y. SITANAKA et al.

Table 7. Coefficients of digestibility, and apparent digestible nutrient in diets with and without addition of an enzyme complex for castrated male swine in the growth-I, growth-II, and finishing phases.

\begin{tabular}{|c|c|c|c|c|c|c|c|}
\hline \multicolumn{8}{|c|}{ Growth-I } \\
\hline & $\overline{\mathrm{PC}}$ & $\mathrm{NC85}$ & EC85 & $\mathrm{NC100}$ & $\overline{E C 100}$ & $\mathrm{CV} \%$ & $\bar{p}$ \\
\hline CDDM (\%) & $93.77^{\mathrm{a}}$ & $93.32^{\mathrm{ab}}$ & $91.84^{\mathrm{bc}}$ & $91.58^{\mathrm{bc}}$ & $90.66^{\mathrm{c}}$ & 1.32 & 0.0001 \\
\hline ADDM (\%) & $82.84^{\mathrm{a}}$ & $81.88^{\mathrm{ab}}$ & $81.04^{\mathrm{bc}}$ & $80.68^{\mathrm{bc}}$ & $79.93^{c}$ & 1.32 & 0.0002 \\
\hline CDCP (\%) & $71.57^{\mathrm{a}}$ & $61.73^{\mathrm{ab}}$ & $62.62^{\mathrm{ab}}$ & $64.70^{\mathrm{ab}}$ & $60.91^{\mathrm{b}}$ & 10.61 & 0.0317 \\
\hline DP (\%) & $13.43^{\mathrm{a}}$ & $10.74^{\mathrm{b}}$ & $11.43^{\mathrm{b}}$ & $11.82^{\mathrm{ab}}$ & $11.41^{\mathrm{b}}$ & 10.58 & 0.0031 \\
\hline CDCE $(\%)$ & $76.48^{\mathrm{a}}$ & $71.51^{\mathrm{ab}}$ & $69.48^{\mathrm{b}}$ & $75.03^{\mathrm{ab}}$ & $70.71^{\mathrm{ab}}$ & 6.00 & 0.0163 \\
\hline $\mathrm{DE}(\mathrm{kcal} / \mathrm{kg})$ & $3,020.4^{\mathrm{a}}$ & $2,749.2^{\mathrm{b}}$ & $2,650.4^{b}$ & $3,245.3^{\mathrm{a}}$ & $3,047.6^{\mathrm{a}}$ & 5.70 & 0.0000 \\
\hline \multicolumn{8}{|c|}{ Growth-II } \\
\hline CDDM (\%) & 91.16 & 93.41 & 92.39 & 93.57 & 93.54 & 2.14 & 0.0985 \\
\hline ADDM (\%) & 81.30 & 82.56 & 81.48 & 82.42 & 82.39 & 2.15 & 0.4834 \\
\hline CDCP (\%) & 72.51 & 74.00 & 72.29 & 72.57 & 79.62 & 6.85 & 0.0376 \\
\hline DP (\%) & $13.36^{\mathrm{bc}}$ & $13.63^{b}$ & $12.9^{\mathrm{bc}}$ & $12.2^{\mathrm{c}}$ & $15.36^{\mathrm{a}}$ & 6.85 & 0.0000 \\
\hline CDCE (\%) & 80.38 & 81.54 & 80.58 & 81.30 & 84.79 & 4.16 & 0.0960 \\
\hline $\mathrm{DE}(\mathrm{kcal} / \mathrm{kg})$ & $3,548.9$ & $3,563.0$ & $3,453.0$ & $3,585.7$ & $3,599.4$ & 4.19 & 0.3055 \\
\hline \multicolumn{8}{|c|}{ Finishing } \\
\hline CDDM (\%) & $94.39^{\mathrm{a}}$ & $92.48^{b}$ & $92.50^{\mathrm{ab}}$ & $92.13^{b}$ & $93.51^{\mathrm{ab}}$ & 1.36 & 0.0096 \\
\hline ADDM (\%) & $83.31^{\mathrm{a}}$ & $82.12^{\mathrm{ab}}$ & $81.55^{\mathrm{b}}$ & $81.30^{\mathrm{b}}$ & $82.42^{\mathrm{ab}}$ & 1.35 & 0.0140 \\
\hline CDCP (\%) & $83.34^{\mathrm{a}}$ & $74.31^{\mathrm{c}}$ & $76.04^{\mathrm{bc}}$ & $77.16^{\mathrm{bc}}$ & $81.13^{\mathrm{ab}}$ & 5.13 & 0.0007 \\
\hline DP (\%) & $12.75^{\mathrm{b}}$ & $12.51^{\mathrm{b}}$ & $12.89^{\mathrm{b}}$ & $12.38^{\mathrm{b}}$ & $13.93^{\mathrm{a}}$ & 5.15 & 0.0008 \\
\hline CDCE (\%) & $88.60^{\mathrm{a}}$ & $81.95^{\mathrm{c}}$ & $82.99^{\mathrm{bc}}$ & $83.88^{\mathrm{bc}}$ & $86.72^{\mathrm{ab}}$ & 2.94 & 0.0001 \\
\hline $\mathrm{DE}(\mathrm{kcal} / \mathrm{kg})$ & $3,789.4^{\mathrm{a}}$ & $3,109.5^{\mathrm{d}}$ & $3,541.7^{\mathrm{bc}}$ & $3,501.9^{c}$ & $3,686.9^{\mathrm{ab}}$ & 2.88 & 0.0000 \\
\hline
\end{tabular}

Means followed by different letters in the row differ by the Tukey's test $(p<0.05)$. PC $=$ Positive control diet; NC85 = Negative control diet with energy reduction of $85 \mathrm{kcal} / \mathrm{kg}$ ME; EC85 = NC85 diet with addition of enzyme complex; NC100 = Negative control diet, with energy reduction of $100 \mathrm{kcal} / \mathrm{kg} \mathrm{ME} ; \mathrm{EC} 100=\mathrm{NC} 100$ diet, with addition of enzyme complex. Growth-I (63-90 days old); Growth-II (91-118 days old); Finishing (118-145 days old). $\mathrm{CDDM}=$ coefficient of apparent digestibility of dry matter; $\mathrm{ADDM}=$ apparent digestible dry matter; $\mathrm{CDCP}=$ coefficient of apparent digestibility of crude protein; $\mathrm{DP}=$ Apparent digestible protein; $\mathrm{CDCE}=$ coefficient of apparent digestibility of crude energy; $\mathrm{DE}=$ apparent digestible energy; $\mathrm{CV}=$ coefficient of variation.

The CDDM, CDCP, CDCE, ADDM and DE of the treatments were similar $(p>0.05)$ in growth-II. The DP of in the EC100 treatment was higher $(p<0.05)$ than in the other treatments. This denotes the positive effect of using an enzyme complex in diets with reduction of $100 \mathrm{kcal}$. The treatments NC85 and EC85 had no differences $(p>0.05)$.

In the finishing phase, the coefficients of digestibility of the NC85 and NC100 diets were negatively affected, but the use of enzyme complex in the EC100 was effective. The coefficients of digestibility of these diets were similar to those of the PC, thus, the use of enzymes in diets with energetic reduction of $100 \mathrm{kcal}$ in the finishing phase is efficient and present similar or better results than diets without energetic reduction.

Hurtado Nery et al. (2000) also observed improvement in digestibility of crude protein of a feed based on corn, and soybean meal for swine of 10 to $30 \mathrm{~kg}$ when supplemented with an enzyme complex - amylase, lipase, and protease. This result was different from that found in the present study, in which the energetic values had differences.

The enzyme complex used had xylanase and ß-glucanase, which act on the cell walls of nonstarch polysaccharides and can improve the digestibility of protein and energy components.

Although the enzyme complex also had cellulase, the diets used contained low fiber levels, and the effect of the enzymes on the digestibility of the diet constituents depends on the availability of substrate. This may explain the differences found.

Moreover, the experimental diets were composed of plant origin ingredients, i.e., they contained another antinutritional factor for monogastrics, the phytate. It may affect negatively the energy use, possibly by inhibiting the $\alpha$-amylase enzyme activity or decreasing dietary protein digestibility (SELLE; RAVINDRAN, 2008). However, the enzyme complex had the enzyme phytase, capable of acting on phytate and make available nutrients that were complexed with phytic acid molecules (RUIZ et al., 2008), and thus providing higher digestibility.

The use of phytase singly in swine diets may be not effective due to the lack of access to the substrate, when it is complexed to non-starch polysaccharides (BARBOSA et al., 2008). However, xylanase can degrade the PNA layers by depolymerization of arabinoxylans (BARBOSA et al., 2012), which facilitates the action of phytase on the phytate stored in the cell wall (OLUKOSI; COWIESON; ADEOLA, 2007) and the access of endogenous and exogenous enzymes to the encapsulated nutrients, increasing the availability of nutrients. 
The performance of castrated males fed the EC85 diet was positively affected. The improvement in nutrient digestibility found indicates that the enzyme complex may have had beneficial effects on nutrient digestibility and, consequently, on the animals' performance, by breaking the cell wall structures of plants used in the diet and releasing the nutrients contained in the cell wall.

The results of the economic analysis of the diets with and without the enzyme complex offered to female and castrated male swine are presented in Tables 8 and 9 , respectively.

Table 8. Feed cost per $\mathrm{kg}$ (BRL/kg feed), feed cost per $\mathrm{kg}$ of live weight gain (BRL/kg WG), and economic efficiency index $(\mathrm{EEI} \%)$ of female swine fed diets with or without enzyme complex, evaluated in the Periods I, II and III.

\begin{tabular}{|c|c|c|c|c|c|}
\hline & $\mathrm{PC}$ & NC85 & EC85 & NC100 & EC100 \\
\hline \multicolumn{6}{|l|}{ Period I } \\
\hline $\mathrm{BRL} / \mathrm{kg}$ feed & 0.74 & 0.67 & 0.68 & 0.66 & 0.68 \\
\hline Consumed Feed Cost BRL/Kg WG & 1.23 & 1.23 & 1.23 & 1.28 & 1.22 \\
\hline EEI\% & 99.18 & 99.18 & 99.18 & 95.13 & 100.00 \\
\hline \multicolumn{6}{|l|}{ Period II } \\
\hline $\mathrm{BRL} / \mathrm{kg}$ feed & 0.67 & 0.62 & 0.63 & 0.62 & 0.64 \\
\hline Consumed Feed Cost BRL/Kg WG & 1.31 & 1.44 & 1.45 & 1.45 & 1.43 \\
\hline EEI\% & 100 & 90.97 & 90.34 & 90.34 & 91.60 \\
\hline \multicolumn{6}{|l|}{ Period III } \\
\hline $\mathrm{BRL} / \mathrm{kg}$ feed & 0.63 & 0.59 & 0.60 & 0.59 & 0.61 \\
\hline Consumed Feed Cost BRL/Kg WG & 1.42 & 1.44 & 1.45 & 1.44 & 1.44 \\
\hline EEI\% & 100.00 & 98.61 & 97.93 & 98.61 & 98.61 \\
\hline
\end{tabular}

$\mathrm{PC}=$ Positive control diet; NC85 = Negative control diet with energy reduction of $85 \mathrm{kcal} / \mathrm{kg} \mathrm{ME}$; EC85 = NC85 diet with addition of enzyme complex; NC100 = Negative control diet, with energy reduction of $100 \mathrm{kcal} / \mathrm{kg} \mathrm{ME}$; EC100 $=\mathrm{NC100}$ diet, with addition of enzyme complex. Period I (63-90 days old); Period II (63-118 days old); Period III (63-145 days old). Costs of the diets based on prices in the State of São Paulo, Brazil, in August 13, 2013, considering USS $1.00=$ BRL 2.60.

Table 9. Feed cost per $\mathrm{kg}$ (BRL/kg feed), feed cost per $\mathrm{kg}$ of live weight gain (BRL/kg WG) and economic efficiency index (EEI\%) of castrated male swine fed diets with or without enzyme complex, evaluated in the Periods I, II and III.

\begin{tabular}{|c|c|c|c|c|c|}
\hline & $\mathrm{PC}$ & NC85 & EC85 & NC100 & EC100 \\
\hline \multicolumn{6}{|l|}{ Period I } \\
\hline $\mathrm{BRL} / \mathrm{kg}$ feed & 0.74 & 0.67 & 0.68 & 0.66 & 0.68 \\
\hline Consumed Feed Cost BRL/Kg WG & 1.16 & 1.30 & 1.12 & 1.13 & 1.14 \\
\hline $\mathrm{EEI} \%$ & 96.55 & 86.15 & 100.00 & 99.11 & 98.24 \\
\hline \multicolumn{6}{|l|}{ Period II } \\
\hline $\mathrm{BRL} / \mathrm{kg}$ feed & 0.67 & 0.62 & 0.63 & 0.62 & 0.64 \\
\hline Consumed Feed Cost BRL/Kg WG & 1.22 & 1.42 & 1.35 & 1.36 & 1.34 \\
\hline $\mathrm{EEI} \%$ & 100 & 85.91 & 90.37 & 89.70 & 91.10 \\
\hline \multicolumn{6}{|l|}{ Period III } \\
\hline $\mathrm{BRL} / \mathrm{kg}$ feed & 0.63 & 0.59 & 0.60 & 0.59 & 0.61 \\
\hline Consumed Feed Cost BRL/Kg WG & 1.33 & 1.51 & 1.39 & 1.42 & 1.44 \\
\hline $\mathrm{EEI} \%$ & 100.00 & 88.00 & 95.68 & 93.66 & 92.36 \\
\hline
\end{tabular}

$\mathrm{PC}=$ Positive control diet; NC85 = Negative control diet with energy reduction of $85 \mathrm{kcal} / \mathrm{kg} \mathrm{ME}$; EC85 = NC85 diet with addition of enzyme complex; NC100 = Negative control diet, with energy reduction of $100 \mathrm{kcal} / \mathrm{kg} \mathrm{ME} ; \mathrm{EC} 100=\mathrm{NC100}$ diet, with addition of enzyme complex. Period I (63-90 days old); Period II (63-118 days old); Period III (63-145 days old). Costs of the diets based on prices in the State of São Paulo, Brazil, in August 13, 2013, considering USS 1.00 = BRL 2.60.

The diets containing the enzyme complex presented lower cost than the PC diet treatment. Those diets had an increased nutritional value, i.e., there was a reduction of the nutritional levels of the diet and an inclusion of enzymes, representing a cost saving in the diet.

The EC100 diet was more economically viable for females in Period I; however, the PC treatment was most efficient in the Periods II and III.

The EC85 treatment was more economically viable for males in Period I. In the following phases, although it was less efficient than PC, it was more efficient than its negative control (NC85) and the EC100.

These results indicate that male and female pigs present different responses to energy reduction and supplementation with enzyme complexes in the Period I, since the more feasible treatments were the EC85 for males and EC100 for females.

This denotes that the use of enzymes in 
certain periods can favor the weight gain of animals, although the cost of the enzyme diets is higher when compared to the controls (without the addition of enzymes). These results are consistent with those found by Silva et al. (2013), who also found more economically efficient diets when using enzymes.

\section{CONCLUSIONS}

The use of enzyme complex in diets with reduction of $85 \mathrm{kcal} / \mathrm{kg} \mathrm{ME}$ is recommended for male swine during growth and finishing phases. It improves feed conversion and is more economically efficient during the growth-I phase. The use of enzyme complex is not justified for female swine.

The use of the enzyme complex in the diets with energy reduction of $100 \mathrm{kcal} / \mathrm{kg}$ ME increased the digestible protein content during the growth-II phase. The addition of enzyme complex in the diets with energy reduction of 85 and $100 \mathrm{kcal} / \mathrm{kg} \mathrm{ME}$ increased the digestible energy contents in the diets for swine in the finishing phase.

\section{REFERENCES}

BARBOSA, N. A. A. et al. Enzimas exógenas no desempenho e na digestibilidade ileal de nutrientes em frangos de corte. Pesquisa Agropecuária Brasileira, Brasília, v. 43, n. 6, p. 755-762, 2008.

BARBOSA, N. A. A. et al. Enzimas exógenas em dietas de frangos de corte: desempenho. Ciência Rural, Santa Maria, v. 42, n. 8, p. 1497-1502, 2012.

BELLAVER, C. et al. Radícula de malte na alimentação de suínos em crescimento e terminação. Pesquisa Agropecuária Brasileira, Brasília, v. 20, n. 8, p. 969-974, 1985.

CANTARELLI, V. S. et al. Composição química, vitreosidade e digestibilidade de diferentes híbridos de milho para suínos. Ciência e Agrotecnologia, Lavras, v. 31, n. 3, p. 860-864, 2007.

CARDOSO, D. M. et al. Uso de enzimas exógenas na avicultura: uma visão crítica, Boletim da Indústria Animal, Nova Odessa, v. 67, n. 2, p. 191198, 2010.

CARVALHO, A. A. et al. Digestibilidade aparente de dietas e metabolismo de frangos de corte alimentados com dietas contendo soja integral processada. Ciência Rural, Santa Maria, v. 38, n. 2, p. 477-483, 2008.

CARVALHO, D. C. O. et al. Coeficiente de digestibilidade verdadeira dos aminoácidos e valores de aminoácidos digestíveis de milho submetido a diferentes temperaturas de secagem e períodos de armazenamento. Revista Brasileira de Zootecnia, Viçosa, v. 38, n. 5, p. 850-856, 2009.

FERREIRA, D. F. Sisvar: a computer statistical analysis system. Ciência e Agrotecnologia, Viçosa, v. 35, n. 6, p. 1039-1042, 2011.

HAUSCHILD, L. et al. Utilização do triticale e de enzimas em dietas para suínos: digestibilidade e metabolismo. Arquivo Brasileiro de Medicina Veterinária e Zootecnia, Belo Horizonte, v. 60, n. 2, p. 470-476, 2008.

HURTADO NERY, V. L. et al. Adição de enzimas exógenas para leitões dos 10 aos $30 \mathrm{~kg}$ de peso. Revista Brasileira de Zootecnia, Viçosa, v. 29, n. 3, p. 794-802, 2000.

KIARIE, E.; ROMERO, L. F.; NYACHOTI, C. M. The role of added feed enzymes in promoting gut health in swine and poultry. Nutrition Research Reviews, Cambridge, v. 26, n. 1, p. 71-88, 2013.

KIM, S. W. et al. Use of carbohydrases in cornsoybean meal based grower-finisher pig diets. Animal Research, Cambridge, v. 55, n. 6, p. $563-$ 578, 2006.

LEWIS, A. J. Amino acids in swine nutrition. In: LEWIS, A. J.; SOUTHERN, L. L. (Eds.). Swine nutrition. 2thed. Boca Raton: CRC press, 2001. p. 131-141

LIMA, M. R. et al. Enzimas exógenas na alimentação de aves. Acta Veterinaria Brasilica, Mossoró, v. 1, n. 4, p. 99-110, 2007.

LORENA-REZENDE, I. M. B. L. et al. Digestibility of the cottonseed meal with or without addition of protease and phytase enzymes in swine diet. Acta Scientiarum, Maringá, v. 34, n. 3, p. 259-265, 2012.

LUDKE, M. C. M. M. et al. Soja integral processada de diferentes formas para uso em dietas para suínos em crescimento e terminação. Revista Brasileira de Zootecnia, Viçosa, v. 36, n. 5, p. 1566-1572, 2007.

MATHLOUTHI, N. et al. Effects of xylanase and bglucanase addition on performance, nutrient digestibility, and physico-chemical conditions in the small intestine contents and caecal microflora of broiler chickens fed a wheat and barley-based diet. Animal Research, Cambridge, v. 51, n. 5, p. 395406, 2002.

NATIONAL RESEARCH COUNCIL - NRC. Subcommittee on Swine Nutrition. Committee on Animal Nutrition. Nutrient requeriments of swine. 
11. ed. Washington: National Academy Press, 2012. $400 \mathrm{p}$.

OLUKOSI, O. A.; COWIESON, A. J.; ADEOLA, O. Age-related influence of a cocktail of xylanase, amylase, and protease or phytase individually or in combination in broilers. Poultry Science, Champaing, v. 86, n. 1, p. 77-86, 2007.

RODRIGUES, P. B. et al. Desempenho de frangos de corte, digestibilidade de nutrientes e valores energéticos de rações formuladas com vários milhos, suplementadas com enzimas. Revista Brasileira de Zootecnia, Viçosa, v. 32, n. 1. p. 171-182, 2002.

ROSTAGNO, H. S. et al. Tabelas brasileiras para aves e suínos: composição de alimentos e exigências nutricionais. 3. ed. Viçosa, MG: UFV, 2011. 252 p.

RUIZ, U. S. et al. Complexo enzimático para suínos: digestão, metabolismo, desempenho e impacto ambiental. Revista Brasileira de Zootecnia, Viçosa, v. 37, n. 3 , p. $458-468,2008$.

RUIZ, U. S. et al. Enzyme complex supplementation in different nutrient levels diets on pigs feces excretion and anaerobic digestion. Scientia agrícola, Piracicaba, v. 74, n. 3, p. 180-188, 2017.

SAKOMURA, N. K.; ROSTAGNO, H. S. Métodos de pesquisa em nutrição de monogástricos. 2. ed. Jaboticabal, SP: Funep, 2016. 262 p.

SELLE, P. H.; RAVINDRAN, V. Phytate-degrading enzymes in pig nutrition. Livestock Science, Amsterdam, v. 113, n. 2, p. 99-122, 2008.

SILVA, C. A. et al. Utilização de um complexo enzimático para rações contendo farelo de gérmen de milho desengordurado para suínos em fase de crescimento e terminação. Semina: Ciências Agrárias, Londrina, v. 34, n. 6, p. 4065-4082, 2013.

VAN KEULEN, J.; YOUNG, B. A. Evaluation of acid-insoluble ash as natural marker in ruminant digestibility studies. Journal of Animal Science, Champaign, v. 44, n. 2, p. 282-287, 1977.

TAVERNARI, F. C. et al. Efeito da utilização de farelo de girassol na dieta sobre o desempenho de frangos de corte. Revista Brasileira de Zootecnia, Viçosa, v. 38, n. 9, p. 1745-1750, 2009. 